\title{
PENENTUAN NILAI KALOR SERTA PENGARUH ASAM KLORIDA (HCI) TERHADAP KADAR BIOETANOL BONGGOL PISANG (Musa paradisiacal)
}

\author{
${ }^{1}$ H.Asri Saleh, ${ }^{1}$ Jawiana Saokani, ${ }^{1}$ Samsul Rijal \\ 'Jurusan Kimia, Fakultas Sains dan Teknologi, UIN Alauddin Makassar \\ Email: Rijalmuhtar@gmail.com
}

\begin{abstract}
The research of influence bioetanol degree to chlorine acid catalyst concentration $(\mathrm{HCl})$ in the hydrolysis process banana's bump (Musa paradisiacal) has the goal to know the influence of catalyst concentration variation $\mathrm{HCl}$ was given the result of banana's bump hydrolysis which maximum on catalyst variation $\mathrm{HCl} 0,5 \mathrm{M} ; 1,0 \mathrm{M} ; 1,5 \mathrm{M} ; 2,0 \mathrm{M}$ and 2,5 M on temperature $70^{\circ} \mathrm{C}, 150 \mathrm{rpm}$ during 120 minute with appointment of calor percentage on optimum etanol degree. Based on the result of the research etanol degree highest on $\mathrm{HCl}$ with concentration 2,5 with bioetanol degree 5.29\% per 10 gram banana's bump. Based on the ANAVA calculation found out $\mathrm{F}$ calculate $<\mathrm{F}$ table so that $\mathrm{H}_{0}$ accepted and $\mathrm{H}_{1}$ refused. It's mean that there were not influenced of concentration $\mathrm{HCl}$ to bioetanol degree significantly. Percentage of bioetanol calor which found out on concentration $\mathrm{HC1}$ 2,5 M (maximum concentration) were 3461 (Sample I) and 3384 kkal (Sample II).
\end{abstract}

Keyword: Banana bump (Musa paradisiacal), bioethanol, chlorine acid ( $\mathrm{HCl}$ ), hydrolysis,

\section{PENDAHULUAN}

Energi mulai menjadi isu global ketika harga minyak dunia khususnya bahan bakar minyak (BBM) secara tiba-tiba melonjak tajam. Negara-negara di dunia termaksud Indonesia mulai merasakan dampak kenaikan bahan bakar minyak (BBM). Harga minyak mentah dunia menguat ke level US\$ 50 di awal pekan ini (Maret 2015) usai turun tajam, seiring dolar menguat dan pasokan minyak bertambah pada akhir pekan lalu. Kenaikan harga minyak dunia ini mengakibatkan kenaikan harga BBM baik Premium maupun solar sebesar Rp. 500,- per liter. Premium yang sebelumnya 6.400 ,- menjadi 6.900 ,- per liter. Sedangkan solar dari 6.800,menjadi Rp. 7.300. harga tersebut mulai berlaku tanggal 28 Maret 2015 pukul 00.00 WIB (Melani, 2015).

Berbagai negara di dunia telah membangkitkan upaya untuk mencari alternatif sumbersumber energi baru selain minyak bumi seperti nuklir, air, surya, batu bara dan salah satunya adalah memanfaatkan tumbuhan seperti bioetanol. Sudah saatnya Indonesia mengurangi ketergantungan terhadap bahan bakar fosil dengan mengembangkan sumber energi alternatif baru. Salah satu solusinya adalah bioenergi, lebih spesifiknya biofuel atau Bahan Bakar Nabati (BBN) karena Indonesia sangat kaya akan sumber daya alam berupa biomassa yang dapat dimanfaatkan sebagai bahan baku bioenergi salah satunya adalah etanol yang lebih ramah lingkungan (Tazi dan Sulistiana, 2011). 
Etanol banyak digunakan sebagai bahan bakar cair nabati. Etanol dapat diproduksi secara biologi (bioetanol) dimana merupakan alkohol yang didapatkan dari hasil fermentasi bahanbahan yang mengandung gula, pati atau selulosa. Bioetanol merupakan bahan yang sangat penting karena merupakan bahan bakar cair dari sumber yang dapat diperbaharui. Bioetanol tidak seperti bensin, bioetanol merupakan bahan bakar oksigenat dengan kandungan oksigen sebesar 35\% yang dapat mereduksi partikulat dan emisi NOx dari hasil pembakaran (Gusmarwati, 2010) dengan bilangan oktan 106 - 120 bioetanol yang bersifat ramah lingkungan (Piarah dkk, 2010).

Indonesia mempunyai potensi yang sangat besar untuk menghasilkan bioetanol mengingat bahan bakar nabati ini dapat memanfaatkan kondisi geografis dan sumber bahan baku dari berbagai tanaman yang tersedia di Indonesia. Salah satu tanaman yang dapat diproses menjadi bioetanol adalah tanaman pisang. Hampir di setiap tempat di Indonesia dapat dengan mudah ditemukan tanaman pisang. Semua bagian tumbuhan pisang dapat diolah dan dimanfaatkan khususnya sebagai bahan makanan. Bagian tumbuhan pisang yang tidak banyak digunakan untuk bahan makanan adalah bonggol atau batang pohon pisang. Jumlah produksi bonggol pisang di Indonesia mencapai 107,5 Mton per tahun (Gusmarwati, 2010) Bonggol pisang secara teori mengandung $76 \%$ pati, $20 \%$ air, sisanya adalah protein dan vitamin (Yuanita, 2008).

Proses produksi bioetanol secara keseluruhan terdiri dari 3 tahap yaitu hidrolisis pati, fermentasi glukosa dan destilasi etanol. Dimana ketiga tahapan ini sangat mempengaruhi kadar dan kualitas bioetanol yang dihasilkan. Proses hidrolisis secara kimiawi memiliki beberapa keuntungan dibandingakan proses hidrolisis secara biologi yaitu lebih murah, waktu yang dibutuhkan cepat, dijual bebas dipasaran dan nilai konversi glukosanya relatif besar. Berdasarkan penelitian Hidayat, dimana salah satu variabel penelitiannya yaitu pengaruh jenis asam ( $\mathrm{HCl} 5 \%$, $\mathrm{HNO}_{3} 5 \%$ dan $\mathrm{H}_{2} \mathrm{SO}_{4} 2 \%$ ) terhadap nilai dextrose equivalent (DE) dimana nilai ini menyatakan persentase perbandingan total gula pereduksi dengan total gula. Kesimpulan dari penelitian ini adalah jenis asam $\mathrm{HCl} 5 \%$ yang menghasilkan nilai DE tertinggi yaitu sebesar 54,00\%, berarti $\mathrm{HCl}$ memiliki kemampuan paling baik dalam memecah pati tapioka menjadi gula yang lebih sederhana. Pada $\mathrm{HNO}_{3} 5 \%$ dan $\mathrm{H}_{2} \mathrm{SO}_{4} 2 \%$ dihasilkan nilai DE berturut-turut 50,99\% dan 38,51\% (Hidayat, 2006).

Proses fermentasi merupakan tahap yang sangat penting dalam memproduksi bioetanol. Berdasarkan penelitian Solikhin, volume bioetanol tertinggi yaitu sebesar 912,9003 mL etanol/Kg bonggol Pisang dengan konversi glukosa menjadi etanol sebesar 88,77214\% mol, dengan variabel pengaruh waktu dan nutrisi pada proses fermentasi dengan ragi Saccoromycess cereviceae terhadap kadar alkohol (etanol). Kadar etanol tertinggi berdasarkan pengukuran menggunakan alkohol meter atau hydrometer dan metode oksidasi dikromat diperoleh pada sampel dengan starter 8\% dan lama fermentasi 5 hari yaitu sebesar 12,2\% (Solikhin dkk, 2012). 
Salah satu syarat sebagai acuan pengaplikasian bioetanol terhadap mesin kendaraan ialah nilai kalor bioetanol tersebut, yang biasanya dikombinasikan terhadap premium.

Berdasarkan penelitian Wiratmaja, dengan judul Pengujian Karakteristik Fisika Biogasoline Sebagai Bahan Bakar Alternatif Pengganti Bensin Murni, yang salah satunya menguji nilai kalor campuran bensin:etanol 95\% dengan variasi (90:10), (85:15) dan (80:20). Dari hasil pengujian Karakteristik fisika biogasoline dengan perbandingan bensin:etanol 95\% (90:10), ternyata paling mendekati karakter fisika dari bensin. Dimana nilai kalornya mendekati 20.800 (btu/lb) (Wiratmaja, 2010). Berdasarkan uraian tersebut maka dilakukanlah penelitian dengan judul "Penentuan Nilai Kalor Serta Pengaruh Konsentrasi Asam Klorida Terhadap Kadar Bioetanol dari Bonggol Pisang (Musa paradisiacal)".

\section{Tujuan}

Tujuan penelitian untuk mengetahui:

1. Berapa konsentrasi optimum asam klorida $(\mathrm{HCl})$ untuk menghasilkan kadar bioetanol tertinggi dari pati bonggol pisang?

2. Berapa nilai kalor bakar bioetanol pati bonggol pisang?

\section{METODE PENELITIAN}

\section{Alat}

Penelitian ini menggunakan bomb kalorimeter, satu set rangkaian alat destilasi, shaker waterbath, sieve shaker, oven, desikator, neraca analitik, $\mathrm{pH}$ meter, piknometer, blender, termometer, alat-alat gelas, statif dan klem.

\section{Bahan}

Bahan yang digunakan dalam penelitian ini antara lain ammonium sulfat $\left(\mathrm{NH}_{4}\right)_{2} \mathrm{SO}_{4}$, aluminium foil, asam klorida $(\mathrm{HCl})$, asam sulfat $\left(\mathrm{H}_{2} \mathrm{SO}_{4}\right)$, aquabidest, aquades, larutan benedict, larutan iod, bonggol pisang, kalium dikromat $\left(\mathrm{K}_{2} \mathrm{Cr}_{2} \mathrm{O}_{7}\right)$, kertas saring, natrium hidroksida $(\mathrm{NaOH}), \mathrm{NPK}$, ragi fermipan (Saccharomyces cereviseae).

\section{Prosedur Kerja}

\section{Preparasi Sampel}

Sebanyak 3 buah bonggol pisang yang telah dipanen buahnya dikupas dan dibersihkan setelah itu dipotong secara tipis bonggol pisang yang telah bersih kemudian di jemur hingga kering. Bonggol pisang yang telah kering dihaluskan dengan menggunakan blender, kemudian diayak hasil blender dengan ukuran ayakan $(+40,+100)$ mesh. 


\section{Penentuan Kadar Air}

Disiapkan cawan porselin sebanyak 3 buah kemudian diaktivasi ke dalam oven selama 1 jam pada suhu $105^{\circ} \mathrm{C}$ lalu didesikator selama 15 menit, dan ditimbang bobot kosong masingmasing cawan. Selanjutnya diisi masing-masing cawan dengan sampel bonggol pisang hasil ayakan, lalu ditimbang bobot awal dan dipanaskan dalam oven selama 1 jam pada suhu $105^{\circ} \mathrm{C}$ selanjutnya didinginkan dalam desikator selama 15 menit, kemudian ditimbang bobot akhirnya yang konstan.

\section{Hidrolisis Pati Bonggol Pisang}

Tepung bonggol pisang ditimbang sebanyak 10 gram dan dimasukkan ke dalam erlenmeyer $250 \mathrm{~mL}$ kemudian ditambahkan $100 \mathrm{~mL}$ asam klorida $(\mathrm{HCl})$ dengan variasi konsentrasi $0,5 \mathrm{M} ; 1,0 \mathrm{M} ; 1,5 \mathrm{M} ; 2,0 \mathrm{M}$ dan 2,5 M, selanjutnya dihidrolisis dalam shaker water bath dengan kecepatan $150 \mathrm{rpm}$ pada suhu $70^{\circ} \mathrm{C}$ selama 120 menit. Setelah itu ditambahkan $\mathrm{NaOH} 6 \mathrm{~N}$ tetes per tetes ke dalam hasil hidrolisis hingga mencapai $\mathrm{pH} 5$. Proses hidrolisis dilakukan secara duplo.

\section{Fermentasi Pati Bonggol Pisang dengan Asam Klorida}

Proses fermentasi dilakukan dengan mengambil $100 \mathrm{~mL}$ glukosa yang telah dihidrolisis dengan variasi $\mathrm{HCl}$, setelah itu ditambahkan 5 tetes ammonium sulfat (ZA) 2\% dan 5 tetes NPK $2 \%$ sebagai nutrien. Kemudian ditambahkan ragi fermipan (Saccharomyces cereviseae) 6 gram dan difermentasi selama 5 hari. Setelah itu didestilasi hasil fermentasi pada suhu $78^{\circ} \mathrm{C}$.

\section{Uji Kualitatif dan Kuantitatif Etanol}

Uji kualitatif etanol dilakukan dengan cara dipipet $2 \mathrm{~mL}$ kalium dikromat $2 \%$ ke dalam tabung reaksi, kemudian ditambahkan 6 tetes asam sulfat pekat lalu dihomogenkan. Setelah homogen kemudian ditambahkan $1 \mathrm{~mL}$ sampel yang akan diuji. Hasil positif etanol ditandai dengan perubahan larutan dari jingga menjadi biru.

Uji kuantitatif bioetanol dilakukan dengan metode piknometer. piknometer terlebih dahulu diaktivasi di dalam oven selama 10 menit pada suhu $105^{\circ} \mathrm{C}$ kemudian didesikator. Setelah itu ditimbang bobot kosong piknometer. Kemudian dipipet aquades ke dalam piknometer hingga benar-benar terisi penuh dan ditimbang kembali piknometer yang telah terisi air. Prosedur diatas diulang dengan cara aquades diganti dengan sampel yang akan di uji dan pengujian dilakukan secara duplo. 


\section{Pengukuran Nilai Kalor Bioetanol dari Pati Bonggol Pisang}

Bahan bakar (sampel) ditimbang sebanyak \pm 1 gram (campuran pelet rumput yang telah di ketahui nilai kalornya + sampel bioetanol) kemudian dipasang kawat penyala pada tangkai penyala. Cawan yang berisi bahan bakar ditempatkan pada ujung tangkai penyala kemudian jaket bom ditutup dengan kuat dan diisi oksigen ke dalam bom menggunakan tekanan 25 atm. Jaket bom yang telah terpasang ditempatkan ke dalam kalorimeter kemudian dimasukkan air pendingin sebanyak $2000 \mathrm{~mL}$. Alat bom kalorimeter ditutup dengan alat penutupnya dan pengaduk air pendingin dihidupkan selama 5 (lima) menit sebelum pembakaran dilakukan. Temperatur air pendingin dibaca kemudian digidupkan penyalaan. Air pendingin diaduk selama 5 (lima) menit setelah penyalaan berlangsung kemudian dibaca dan dicatat kembali temperatur air pendingin dan pengaduk dimatikan.

\section{HASIL DAN PEMBAHASAN}

\section{Pengaruh Konsentrasi HCl Terhadap Kadar Bioetanol dari Pati Bonggol Pisang}

Secara garis besar proses produksi bioetanol dari pati bonggol pisang dibagi menjadi 2 tahapan yaitu proses hidrolisis dan fermentasi. Kedua proses ini berpengaruh besar terhadap hasil produksi bioetanol dari pati bonggol pisang. Proses hidrolisis pati bonggol pisang bertujuan untuk memecah makromolekul pati menjadi monomer gula pereduksi.

Proses ini diawali oleh pengayakan pati bonggol pisang yang telah halus dengan ukuran ayakan $(+40,+100)$ mesh, dalam faktor-faktor yang mempengaruhi laju reaksi ukuran partikel juga berperan terhadap reaksi kimia. Penyeragaman ukuran partikel bertujuan untuk menyamakan pengaruh tumbukan dan pergerakan molekul dalam reaksi kimianya, sehingga energi yang digunakan relatif sama dan secara langsung dapat meningkatkan nilai kecepatan reaksi.

Berdasarkan hasil penelitian, kadar air bonggol pisang basah adalah 94,87\%, sedangkan setelah proses pengeringan kadar air dapat menyusut menjadi $11,04 \%$. Kadar air yang baik untuk penyimpanan suatu bahan agar tidak terganggu oleh organisme perusak adalah kurang dari $10 \%$. Dapat disimpulkan bonggol pisang yang digunakan dalam penelitian rentan terganggu oleh organisme perusak, sehingga bonggol pisang yang telah kering harus secepatnya diproses ketahapan selanjutnya.

Pada tahap hidrolisis, pati bonggol pisang akan direaksikan dengan air dan asam klorida sebagai katalisator pada suhu, waktu dan pengadukan optimum. Variabel yang diamati adalah variasi asam klorida $\mathrm{HCl} 0,5 \mathrm{M} ; 1,0 \mathrm{M} ; 1,5 \mathrm{M} ; 2,0 \mathrm{M}$ dan 2,5 M, dengan waktu 120 menit dan suhu $70^{\circ} \mathrm{C}$. Berdasarkan faktor laju reaksi, faktor katalis sangat berpengaruh terhadap hasil reaksi kimia yang terjadi, dimana pada proses hidrolisis ini, semakin tinggi konsetrasi $\mathrm{H}^{+}$dalam larutan maka semakin tinggi pula tumbukan antara molekul-molekul air dan molekul-molekul pati 
sehingga semakin cepat reaksinya, sehingga hasil hidrolisis yang didapatkan akan semakin tinggi.

Berdasarkan hasil penelitian pada proses hidrolisis, secara visual larutan hasil hidrolisis pati bonggol pisang menunjukan degradasi warna coklat yang berbeda. Terbentuknya degradasi warna pada hasil hidrolisis pati bonggol pisang menunjukan tingkat kepekatan atau konsentrasi glukosa yang berbeda pada masing-masing variasi asam klorida.

Penggunaan asam klorida sebagai katalisator hidrolisis karena asam klorida $(\mathrm{HCl})$ merupakan asam kuat yang bersifat monoprotik. Dimana proses pembentukan $\mathrm{H}^{+}$terjadi dalam 1 tahap, sehingga reaksi hidrolisis yang dikatalisnya berlangsung realtif cepat dibandingkan dengan $\mathrm{H}_{2} \mathrm{SO}_{4}$. Selain faktor tersebut, asam klorida juga merupakan asam kuat yang relatif aman, karena pada proses penetralan dengan menggunakan $\mathrm{NaOH}$ akan menghasilkan $\mathrm{NaCl}$ yang tidak berbahaya, apabila dibandingkan dengan $\mathrm{HNO}_{3}$ yang akan menghasilkan gas $\mathrm{NO}_{2}$ yang sangat beracun.

Proses fermentasi merupakan proses pengubahan gula pereduksi hasil hidirolisis menjadi bioetanol, dimana pada penelitian ini menggunakan ragi fermipan yang mengandung biakan Saccharomyces cereviseae. Uji kemurnian dan kehidupan biakan Saccharomyces cereviseae pada ragi fermipan ditandai dengan munculnya gelembung-gelembung gas pada saat ragi dilarutkan dalam air, dimana gelembung tersebut terus bertambah.

Proses fermentasi dilakukan selama 5 hari, yang merupakan waktu optimum Saccharomyces cereviseae untuk mengubah molekul-molekul glukosa menjadi bioetanol. Karena berdasarkan penelitian Nurjati Solikhin (2012), pada hari ke 5 proses fermentasi akan terhenti karena sebagian besar glukosa telah diubah menjadi bioetanol, serta nutrien yang digunakan telah menipis, sehingga menyebabkan sebagian besar Saccharomyces cereviseae mati. Nutrien yang digunakan dalam proses fermentasi adalah 2\% NPK dan $2 \%$ ZA, dimana kandungan nitrogen dan karbon di dalam kedua senyawa tersebut merupakan nutrisi yang baik bagi Saccharomyces cereviseae untuk bertahan hidup.

Selain waktu yang optimum, Saccharomyces cereviseae juga bekerja pada $\mathrm{pH} 5$, sehingga larutan glukosa hasil hidrolisis terlebih dahulu diatur pH-nya dengan cara menambahkan larutan $\mathrm{NaOH}$ hingga mendapatkan $\mathrm{pH}$ yang diinginkan, dimana hasil penetralan larutan uji membentuk lapisan garam $(\mathrm{NaCl})$. Hasil fermentasi yang dilakukan selama 5 hari menunjukan hasil yang positif, hal ini ditandai munculnya gelembung-gelembung gas pada permukanan larutan fermentasi, serta tercium aroma "tape ketan" pada larutan hasil fermentasi, sehingga dapat di tarik kesimpulan, proses fermentasi berhasil dilakukan dengan menghasilkan sejumlah bioetanol.

Proses selanjutnya adalah destilasi. Etanol menguap pada suhu $76-80^{\circ} \mathrm{C}$. lebih rendah di bawah titik didih air, sehingga penguapan etanol relatif mudah. Bioetanol hasil produksi secara biologi memiliki bau khas yang berbeda dengan etanol sintetis yang diproduksi secara pabrikan. 


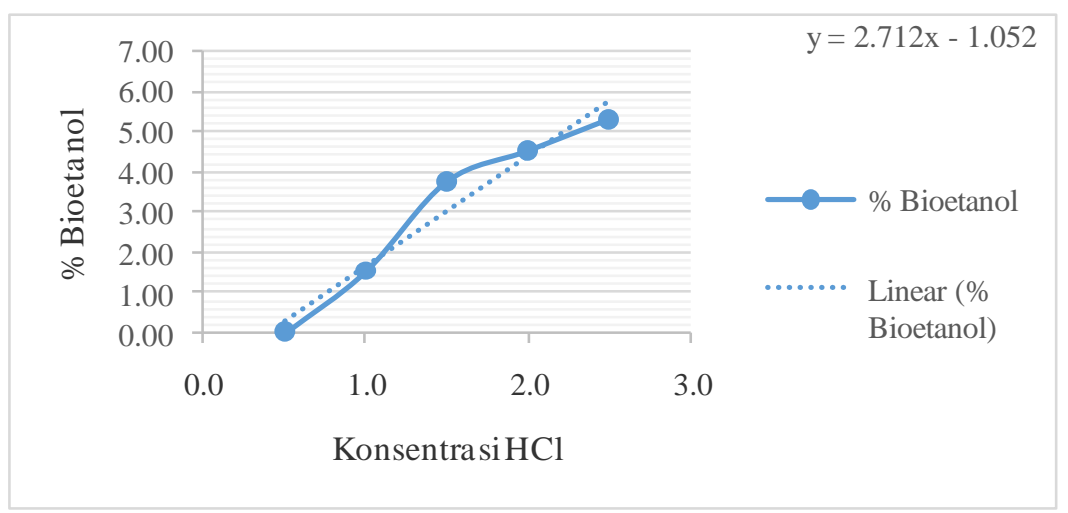

Gambar 1. Kurva Konsentrasi HCl Versus Kadar Bioetanol

Berdasarkan hasil penelitian didapatkan volume bioetanol berturut-turut pada sampel I 17, 20, 9, 21, $19 \mathrm{~mL}$ dan sampel II 8,15, 17, 29, $20 \mathrm{~mL}$. Berdasarkan perhitungan Anava diperoleh $\mathrm{F}$ hitung $(4,92248)<\mathrm{F}$ tabel $(10,13)$ sehingga $\mathrm{H}_{0}$ diterima dan $\mathrm{H}_{1}$ ditolak, yang berarti tidak adanya pengaruh konsentrasi $\mathrm{HCl}$ terhadap kadar bioetanol yang signifikan.

\section{Uji Kualitatif dan Kuantitatif Bioetanol}

Uji kualitatif dilakukan untuk memastikan kandungan bioetanol dalam sampel. Uji kualitatif bioetanol menggunakan metode kalium dikromat $2 \%$ yang direaksikan dengan asam sulfat pekat, dimana campuran kedua larutan ini berwarna jingga, yang secara teori hasil positif mengandung etanol apabila larutan uji berwarna biru (kromium pentoksida). Berdasarkan hasil pengujian sampel etanol, secara keseluruhan warna biru yang dihasilkan tiap masing-masing variasi asam klorida sama, bahkan pengujian pada etanol 70\% dan $90 \%$ menghasilkan warna biru yang sama. Namun yang membedakan tinggi rendahnya konsentrasi bioetanol ialah laju perubahan warna dari jingga menjadi biru. Berdasarkan penelitian uji kalium dikromat pada bioetanol dengan variasi asam klorida, semakin tinggi konsentrasi asam klorida (2,5 M), laju perubahan warnanya semakin cepat. Kemudian dapat disimpulkan semakin tinggi laju perubahan warnanya maka konsentrasi bioetanolnya semakin tinggi, sebagaimana hukum laju reaksi semakin tinggi konsentrasi suatu larutan maka, semakin cepat pula laju reaksinya. Untuk memastikan pengaruh asam klorida terhadap kadar bioetanol yang dihasilkan maka dilakukan uji kuantitatif bioetanol.

Uji kuantitaif bertujuan untuk menentukan kadar (\%) bioetanol yang dihasilkan pada setiap variasi asam klorida. Metode yang digunakan pada uji kuantitatif bioetanol ialah metode penentuan densitas menggunakan piknometer. Berdasarkan hasil penelitian kadar bioetanol yang didapatkan rata-rata sebesar $1-5 \%$ bioetanol per 10 gram bonggol pisang. Nilai tertinggi kadar bioetanol terdapat pada konsentrasi $\mathrm{HCl}$ 2,5 M yaitu sebesar 5.29\%, dengan nilai densitas 0,9916 $\mathrm{g} / \mathrm{mL}$. 
Menurut penelitian Solikhin (2012), volume bioetanol tertinggi yaitu sebesar 912,9003 $\mathrm{mL}$ etanol/Kg bonggol Pisang dengan konversi glukosa menjadi etanol sebesar 88,77214\% mol, dengan variabel pengaruh waktu dan nutrisi pada proses fermentasi dengan ragi Saccoromycess cereviceae terhadap kadar alkohol (etanol). Kadar etanol tertinggi berdasarkan pengukuran menggunakan alkohol meter atau hydrometer dan metode oksidasi dikromat diperoleh pada sampel dengan starter $8 \%$ dan lama fermentasi 5 hari yaitu sebesar $12,2 \%$.

Berdasarkan uji kualitatif bioetanol (uji kalium dikromat 2\%) dengan hasil positif larutan berwarna biru dan uji kuantitaif bioetanol (metode piknometer) dapat dipastikan larutan bening yang dihasilkan pada proses fermentasi merupakan bioetanol dari bonggol pisang.

\section{Nilai Kalor Bioetanol dari Pati Bonggol Pisang}

Proses penentuan nilai kalor bioetanol dari bonggol pisang dilakukan menggunakan metode bom kalorimeter. Prosedur yang dilakukan pada sampel cair secara garis besar sama dengan prosedur yang dilakukan pada sampel padatan, namun yang membedakannya sampel cair harus dibantu pembakarnnya menggunakan pemicu. Pemicu yang digunakan dalam penelitian ini ialah pelet dari rumput dengan nilai kalor (4032 kkal). Penentuan nilai kalornya ditentukan dengan menentukan selisis nilai kalor yang dihasilkan setelah proses pembakaran dengan nilai kalor pemicu pelet rumput.

Tabel 1. Penentuan Nilai Kalor Bioetanol

\begin{tabular}{ccc}
\hline Sampel & $\begin{array}{c}\text { Bioetanol I } \\
(\text { HCl 2,5 M) }\end{array}$ & $\begin{array}{c}\text { Bioetanol II } \\
(\text { HCl 2,5 M) }\end{array}$ \\
\hline $\begin{array}{c}\text { Kadar Bioetanol } \\
(\%)\end{array}$ & 6.54 & 6.06 \\
$\begin{array}{c}\text { Massa Pemicu } \\
\text { (gram) }\end{array}$ & 0,7791 & 0,3412 \\
$\begin{array}{c}\text { Massa Sampel } \\
\text { (gram) }\end{array}$ & 0,8260 & 0,3413 \\
$\begin{array}{c}\text { Suhu Awal }\left({ }^{\circ} \mathrm{C}\right) \\
\text { Suhu Akhir }\left({ }^{\circ} \mathrm{C}\right)\end{array}$ & 24,26 & 25,64 \\
$\begin{array}{c}\text { Kalori Pemicu } \\
\text { (kkal) }\end{array}$ & 4032 & 27,77 \\
$\quad \begin{array}{c}\text { Total Kalori } \\
\text { Pemicu (kkal) }\end{array}$ & 4322 & 4032 \\
$\begin{array}{c}\text { Kalor Bioetanol } \\
\text { (kkal) }\end{array}$ & 3461 & 3384 \\
\hline
\end{tabular}


Berdasarkan uji nilai kalor menggunakan alat bom kalorimeter, didapatkan nilai kalor bioetanol pada konsentrasi $\mathrm{HCl}$ 2,5 M (kadar etanol tertinggi) adalah 3461 kkal (Sampel I) dan 3384 kkal (Sampel II). Dimana pada sampel I kadar etanolnya lebih tinggi dibandingkan dengan sampel II. Berdasarkan penelitian Fitas Afan (2013). Nilai kalor premium $=11.414,453$ $\mathrm{kal} / \mathrm{gram}$; campuran etanol 5\% = 8905,921 kal/gram; $15 \%=8717 \mathrm{kal} / \mathrm{gram}$ dan $25 \%=8358,941$ kal/gram. Konsumsi bahan bakar erat hubungannya dengan nilai kalor bakar, yaitu semakin besar nilai kalor bahan bakar, maka nilai konsumsi bahan bakar semakin kecil. Akan tetapi dalam penelitian ini, campuran premium dan etanol yang mampu menghasilkan tenaga lebih besar sama dengan premium murninya, akan di dapat nilai konsumsi bahan bakar yang lebih rendah dari nilai konsumsi bahan bakar premium itu sendiri. Yang mana membuktikan bahwa penambahan etanol pada bahan bakar premium mampu memberikan efisiensi termal pada raaksi pembakaran dalam mesin. Dengan adanya efisiensi termal pemborosan panas panas yang terjadi dalam mesin akibat hasil pembakaran bahan bakar yang melebihi suhu yang dibutuhkan berkurang. Sehingga kerja mesin semakin irit bahan bakar.

Dapat disimpulkan nilai kalor bioetanol yang dihasilkan dari bonggol pisang sampel I sebesar 3461 kkal dengan kadar bioetanol sebesar 6.54\% dan sampel II 3384 kkal dengan kadar bioetanol sebesar $6.06 \%$. dengan nilai ini dapat dilihat terjadi tren penurunan nilai kalor bioetanol dari bonggol pisang terhadap kadar bioetanol itu sendiri.

\section{PENUTUP}

\section{Kesimpulan}

Kesimpulan dalam penelitian ini adalah sebagai berikut:

1. Konsentrasi optimum asm klorida $(\mathrm{HCl})$ untuk menghasilkan kadar bioetanol tertinggi adalah 2,5M dengan kadar bioetanol 5,29\% per 10 gram bonggol pisang dan tidak ada pengaruh yang signifikan variasi konsentrasi katalisator $\mathrm{HCl}$ terhadap hasil hidrolisis bonggol pisang.

2. Nilai kalor bioetanol dari bonggol pisang pada konsentrasi $\mathrm{HCl} 2,5 \mathrm{M}$ adalah sampel 1 sebesar 3461 kkal dengan kadar bioetanol sebesar 6,54\% dan sampel II 3384 kkal dengan kadar bioetanol sebesar 6,06\%.

\section{Saran}

Saran untuk penelitian selanjutnya adalah dapat menentukan nilai kalor bioetanol dari bonggol pisang yang dicampur dengan premium yang dapat diaplikasikan terhadap kendaraan bermotor.

\section{DAFTAR PUSTAKA}

Solikhin, Nurjati, Arum Sakti Prasetyo dan Luqman Buchori."Pembuatan Bioetanol Hasil Hidrolisis Bonggol Pisang Dengan Fermentasi Menggunakan Saccaromycess cereviceae." Teknologi Kimia dan Industri 1, no.1 (2012), h. 128.

Tazi, Imam dan Sulistiana. "Uji Kalor Bakar Bahan Bakar Campuran Bioetanol dan Minyak Goreng Bekas." Neutrino 3, no. 2 (April 2011), h. 163. 
Piarah, Wahyu H., Zuryati Djafar dan Andi Mangkau. "Analisis Penggunaan Gasohol dari Limbah Kulit Pisang Terhadap Prestasi Mesin Motor Bakar Bensin.” Mekanikal 2, no. 1 (Januari 2011), h. 41.

Gusmarwati, Sri Rahayu, dkk. "Pengaruh Perbandingan Berat Padatan dan Waktu Reaksi Terhadap Gula Pereduksi Terbentuk pada Hidrolisis Bonggol Pisang.” Teknik Kimia Indonesia 9, no. 3 (Desember 2010), h. 77.

Hidayat, Mohammad Agung. Fermentasi Asam Laktat Oleh Rhizopus Oryzae Pada Substrat Singkong Hasil Hidrolisis Asam. (Bogor: ITB, 2006) 